Олег Н. Барабанов

\title{
КОНЦЕПТУАЛЬНЫЕ ПОДХОДЫ К ДИАЛОГУ О РАЗЛИЧНОМ ИДЕОЛОГИЧЕСКОМ ПОНИМАНИИ ЕВРОПЕЙСКИХ ЦЕННОСТЕЙ МЕЖДУ РОССИЕЙ И ЕВРОПЕЙСКИМ СОЮЗОМ
}

\section{Пределы сближения в дискуссии об «общих ценностях» (2000-2003 гг.)}

Уход в отставку президента Б.Н. Ельцина 31 декабря 1999 г. и начало президентского срока В.В. Путина создали возможность для пересмотра содержания сотрудничества России и Евросоюза. Формально, в начале 2000го года стороны неоднократно подчеркивали, что в рамках двустороннего партнерства Россия и Евросоюз разделяют принципы демократии, уважения прав человека, верховенства закона и рыночной экономики. Россия постоянно декларировала тезис обисторическом выборев пользу взаимодействия сЕвропой и общности цивилизационных корней и ценностей. Во взаимоотношениях с ЕС категория «общих ценностей» стала играть роль не столько способа демонстрации стремления России развивать курс на сближение с западным миром, сколько подтверждения факта того, что Россия - уж часть западного мира с точки зрения и внешней, и внутренней политики.

Идея интеграции в Европу как исторического выбора России присутствовала в выступлениях первых лиц, как для российской, так и для зарубежной аудитории ${ }^{1}$. В первый срок президентства В.В. Путина этот тезис достиг своего апогея в 2003 году. Совместное заявление, принятое по итогам майского ХІ саммита России и ЕС уже своим названием должно было подчеркнуть особый характер взаимоотношений партнеров: «Трехсотлетие Санкт-Петербурга - три века общности европейской истории и культуры».

1 Послание Федеральному Собранию Российской Федерации, 16 мая 2003 год. Москва, Кремль// Сайт Президента России (электронный ресурc). URL: http://www.kremlin.ru/appears/2003/05/16/1259_type63372type6 3374type82634_44623.shtml 
Несмотря на заявления о единстве цивилизационного и ценностного пространства России и европейских государств, Евросоюз не спешил с отказом от политики «европеизации» в целом и механизма «политической обусловленности» в частности. В представлении европейской общественности и официальных политических лиц, Россия, безусловно, была европейской страной и важнейшим фактором мировой политики. Однако, декларируемый тезис о том, что Россия - европейская страна ставился под сомнение, если речь шла о принципах реализации внутренней политики. Россия в начале 2000x годов уже пересмотрела место и роль категории «общие ценности»в политическом диалоге с ЕС. Евросоюз, напротив, по инерции, и, несмотря на явную непродуктивность механизмов распространения собственной системы ценностей, продолжал придерживаться модели 1990х годов. При этом с внешнеполитической точки зрения, позиции России усиливались, в то время как международные позиции ЕС ослабли. Эти факторы предопределили нарастание относительных трений между партнерами с одной стороны, и частичную маргинализацию категории «общие ценности» в двустороннем диалоге - с другой стороны.

Дискуссия о приверженности России и ЕС общей системе ценностей в большей или меньшей степени оставалась неотъемлемым элементом политического диалога на протяжении всего периода президентства В.В. Путина. С точки зрения содержания, для Евросоюза вопрос о наличии «общих ценностей» с Россией всегда имел четкую внутриполитическую направленность. Дискуссия, как правило, представляла собой европейский анализ тех принципов, в соответствии с которыми в России осуществлялось реформирование законодательной, судебно-правовой, исполнительной систем власти. На разных этапах взаимоотношений акценты могли смещаться от темы соблюдения прав человека, свободы печати и плюрализма в СМИ до правового нигилизма в России, отсутствия независимой судебной власти и уважения права на частную собственность, избирательного правосудия.

В большинстве случаев представители ЕС последовательно акцентировали внимание и критиковали руководство РФ за нарушение прав человека в Чечне. Для ЕС так называемый «разрыв ценностей» присутствовал на операциональном уровне, и именно о нем говорили официальные представители ЕС в рамках саммитов и двусторонних встреч. Действия России в Чечне оставались классическим предметом дискуссии о ценностях на протяжении как минимум первого президентского срока В.В. Путина, в связи с начавшейся в сентябре 1999 года второй чеченской кампанией.

В 2002 году в своем Послании Федеральному Собранию В.В. Путин заявил о завершении военной стадии конфликта в Чечне. Периодические атаки 
со стороны террористов ${ }^{2}$ и ответные спецоперации со стороны российских властей делали тему Чечни, политического урегулирования чеченской проблемы и соблюдения прав человека в этом регионе постоянным фактором официальных и неофициальных встреч представителей России и ЕС.

23 марта 2000 г., накануне саммита России и ЕС в Москве, В.А. Каламанов, специальный представитель Президента РФ в Чечне, был приглашен выступить перед Европейским парламентом.

В подходах России и Евросоюза в контексте чеченского вопроса был явный «разрыв» в определении места и роли категории «общие ценности». Россия пыталась подробно рассказать о своем видении чеченской проблемы европейской общественности, в том числе и с точки зрения уважения прав человека, допустимых и недопустимых методов борьбы с террористической угрозой. Однако, данный жест со стороны РФ, скорее, можно рассматривать как представление российской стратегии в Чечне, чем уступку под давлением европейской стороны.

В итоге дискуссия об «общих ценностях», несмотря на то, что ее содержательную сторону диктовали европейцы, оставалась не более чем символической мерой. Не имея реальных механизмов давления, Евросоюз был вынужден играть роль наблюдателя, который мог вмешиваться и частично влиять на ситуацию, но только после получения формальной или неформальной поддержки ${ }^{3}$ со стороны российского руководства. В итоге действие санкций, введенных Евросоюзом в отношении РФ в декабре 1999 г., было приостановлено. Изучение ситуации в Чечне со стороны Совета ЕС и Комиссии ЕС привело к отмене запрета на использование неизрасходованных средств из программы ТАСИС для России за $1999 \Gamma^{4}$.

10 июля 2000 г. Совет ЕС по общим вопросам принял решение возобновить действие программы ТАСИС на 2000 г. Была начата подготовка Индикативной

2 Серия терактов 2003 года: теракт в Москве на рок-фестивале «Крылья», подрыв военного госпиталя в Моздоке, теракт в электричке Кисловодск - Минводы на перегоне Подкумок-Белый уголь, теракт с использованием смертников в электричке в Ессентуках.

Серия терактов 2004 года: теракт в московском метро, на перегоне между станциями «Автозаводская» и «Павелецкая», в Грозном на стадионе «Динамо», где проходил парад в честь Дня Победы, теракт у станции метро «Рижская» в Москве, террористический акт в Беслане.

3 Совместное заявление Президента Российской Федерации В.В.Путина, Председателя Европейского Совета Ж.Ширака, при содействии Генерального секретаря Совета ЕС/Высокого представителя по обшей внешней политике и политике безопасности ЕС Х.Солана, и Председателя Комиссии Европейских сообществ Р.Проди, 30 октября 2000 г., Париж, Франция. Сайт Президента России (официальный электронный ресурс) URL: http://www.kremlin.ru/events/articles/2000/10/132513/140829.shtml

4 Борко Ю.А. Отношения России с Европейским союзом: текущие проблемы и дальние горизонты/Ю.А. Борко // Европейский союз на пороге XXI века: выбор стратегии развития, под ред. Ю.А.Борко и О.В.Буториной. - М.: Эдиториал УРСС, 2001. - 471 с. - С.393 
программы на 2002 - 2003 гг5 . Вторая половина 2000 г. подтвердила тенденции, ранее проявившиеся в дискуссии об «общих ценностях». Евросоюз шел на определенные уступки российской стороне, признавая ряд принципиальных для России моментов в чеченском вопросе. Совместное заявление сторон по итогам саммита в октябре 2000 г. содержало приемлемую для России формулу: «нахождение политического решения при уважении суверенитета и территориальной целостности РФ» ${ }^{6}$.

В дискуссии об «общих ценностях» в рамках политического диалога с Россией Европейский Союз фактически оказался в «ловушке». Он не обладал механизмами влияния на политику российских властей в Чечне. В то же время Евросоюз не мог отказаться от обсуждения степени приверженности России демократическим принципам и уважению прав человека как основы стратегического партнерства в силу своей внешнеполитической природы. В результате был найден дипломатический выход из ситуации и выбор сделан в пользу обмена мнениями на официальном уровне. В нем отражался европейский подход к проблеме, и в тоже время не ставился под сомнение суверенитет и территориальная целостность РФ.

Террористическая атака против США 11 сентября 2001 года поновому расставила акценты в дискуссии об «общих ценностях» в пользу России. Саммит октября 2001 года, прошедший практически сразу после «11 сентября», был символом риторического единства принципов и методов борьбы с международным терроризмом. Это подтверждали Совместное заявление по итогам саммита октября 2001 года ${ }^{7}$ и Совместное заявление по международному терроризму октября 2001 года ${ }^{8}$.

Изменение внешней среды, роли и места России в решении глобальных проблем, в частности борьбы с международным терроризмом, оказали непосредственное влияние на оценки степени приверженности России «общим ценностям», особенно во внутренней политике. «Европейский союз выразил поддержку усилиям российского руководства, направленным на политическое урегулирование конфликта в Чечне» ${ }^{9}$. Происходило придание легитимного статуса политики России в Чечне со стороны представителей ЕС. В ответ

Европейский Союз: Факты и Комментарии // Институт Европы РАН и Ассоциация Европейских Исследований.- 2001. - Июнь - август. - Выпуск 21. URL: http://www.edc-aes.ru/site/ru/union/archive/vipusk_21.html вета Ж.Ширака, при содействии Генерального секретаря Совета ЕС/Высокого представителя по обшей внешней политике и политике безопасности ЕС Х.Солана, и Председателя Комиссии Европейских сообществ Р.Проди, 30 октября 2000 г., Париж, Франция. Сайт Президента России (электронный ресуPc) URL: http://www.kremlin.ru/events/articles/2000/10/132513/140829.shtml

7 Совместное заявление по итогам саммита Россия - ЕС, октябрь 2001 г., Москва, Кремль.

8 Совместное заявление по международному терроризму, октябрь 2001 г., Москва, Кремль.

9 Совместное заявление по международному терроризму, октябрь 2001 г., Москва, Кремль. 
«Российская Федерация выразила признательность за гуманитарную помощь региону со стороны Европейского союза» ${ }^{10}$.

В 2001 году в дискуссии об «общих ценностях» с доминирующей темой Чечни был зафиксирован окончательный status-quo. Он был обусловлен, во-первых, развитием самой международной среды, во-вторых, активной поддержкой, оказываемой антитеррористической коалиции со стороны России. Представители Евросоюза должны были принять два аспекта российской трактовки вопроса борьбы с региональным и международным терроризмом. Во-первых, неизбежность нарушений прав человека в условиях проведения силовых акций и военных операций. Во-вторых, неприемлемость подмены понятий: политического урегулирование конфликта и борьбы с международным терроризмом. Системы ценностей России и Евросоюза продолжали не совпадать, причем как на концептуальном уровне, так и на операциональном уровне. Если на более ранних этапах Евросоюз пытался осуществить трансформацию российской системы ценностей, то после «11 сентября» формально признавал, хотя и временно, факт возможного параллельного существования.

Главная проблема заключалась в том, что у Евросоюза и России действительно отсутствовало единое видение того, какие методы антитеррористической борьбы являются допустимыми и кто попадает под понятие «террорист».

Это, прежде всего, касалось дела Ахмада Закаева. Европейские официальные лица отказывались признавать в нем террориста, российская сторона, в свою очередь, не считала возможным привлечь его к участию в политическом урегулировании ситуации в Чечне. Европейский Союз, с многолетней культурой пацифизма, отказа от применения силы, а также урегулирования любых конфликтов средствами переговоров, по крайней мере, на уровне официальной риторики, ставил ценность соблюдения прав человека выше ценности обеспечения безопасности любыми доступными средствами в целом. Подобный подход кардинальным образом отличался от российского видения антитеррористической борьбы. Это противоречие рано или поздно должно было проявить себя в дискуссии об «общих ценностях», несмотря на положительный для России внешний контекст, на фоне которого развивался политический диалог с ЕС.

В итоге противоречие раскрылось в дискуссии об «общих ценностях» во второй половине 2002 года в связи с проведением в Дании Всемирного Чеченского конгресса накануне очередного саммита ЕС и Россия. Европейская

10 Совместное заявление по итогам саммита Россия - ЕС, октябрь 2001 г., Москва, Кремль. 
сторона заявляла, что «по Конституции в Дании есть свобода слова, свобода собраний, и у правительства Дании не было каких-либо правовых полномочий, чтобы отменить это мероприятие, так как оно не представляло угрозу общественной безопасности». Российские официальные лица в свою очередь отмечали, что «ведут борьбу с терроризмом не только в Чечне и считает, что необходимо проблемы терроризма и отдельно проблемы политического урегулирования спорных вопросов, какими бы сложными они ни были».

Тем не менее, европейской стороне хотелось бы влиять на процесс мирного урегулирования в Чечне, о чем свидетельствует отдельные внутренние программы Евросоюза. В рамках полугодичной датской программы реализации Коллективной стратегии ЕС по отношению к России присутствовал раздел о содействии укреплению демократии, законности и государственных учреждений. Этот раздел содержал ряд мер Евросоюза, в том числе касавшихся политики в Чечне.

Отсутствие практических инструментов воздействия на РФ с целью изменения ситуации с правами человека в Чечне осложняло реализацию поставленных целей и задач. У ЕС не хватало политической воли и достаточного стимула даже для применения тех незначительных средств, которые уже имелись в распоряжении. «Национальная индикативная программа» ТАСИС по России на 2002 - 2003 гг. условно могла бы выступить в качестве возможного, хотя бы символического инструмента финансового влияния.

Раздел «Национально программы», озаглавленный «Обусловленность», подчеркивал, что «успех реформ зависит от содействия федеральных и местных властей в их проведении». Эта формулировка оставляла мало возможностей для оказания политического давления. Тем не менее, пункт 8 программы упоминал, что финансирование проводится лишь в случае соблюдения условий сотрудничества, зафиксированных в СПС, а также демократических принципов и прав человека, т.е. в случае приверженности «общим ценностям». В течение 2002 - 2003 гг. Евросоюз ни разу не задействовал механизм отказа в финансировании под предлогом выпадения России из общей системы ценностей.

В итоге все возражения по поводу соответствия России «общим ценностям» Евросоюза во время первого и второго чеченских конфликтов можно скорее рассматривать как символические меры. С одной стороны, они отражали озабоченность общественности государств-членов ЕС, с другой указывали на слабость Евросоюза как нормативного субъекта международных отношений на российском направлении. В одном из своих интервью, ведущий российский политолог-международник, Д.Тренин подчеркнул, что действия Евросоюза не 
оказали никакого влияния на политику российских властей в Чечне ${ }^{11}$, эта точка зрения звучала в комментариях западных экспертов ${ }^{12}$.

Россия, напротив, заявляла, что не только способна отстаивать линию невмешательства, но и стать инициатором обсуждения внутренней политики стран-участниц ЕС на степень соответствия «общим ценностям».

Эта новая черта политического диалога ЕC и России более ярко проявилась в 2003 году. До 2003 года Россия почти никогда не выступала в качестве инициатора предмета дискуссии об «общих ценностях». Она лишь отвечала на претензии европейских партнеров. При этом реакция российских властей была, как правило, жесткой, в рамках четко обозначенной линии начала 2000х гг: никакое вмешательство во внутренние дела РФ неприемлемо. Информирование о ситуации в Чечне, интерес к которой со стороны представителей ЕС сохранялся на протяжении всего 2003 года, не предоставлял права влиять на характер политического урегулирования. Европейские партнеры со временем минимизировали риторическое давление на Россию, понимая безрезультативность подобного диалога при отсутствии реальных инструментов воздействия.

Во второй половине 2003 года российская сторона впервые заявила о том, что «проблема соблюдения прав человека - важнейшая проблема современности», реагировать и решать которую необходимо не в отдельно взятом регионе, а повсеместно.

В данном случае была очевидна попытка перенесения дискуссии об «общих ценностях» из плоскости оценки внутренней политики РФ в плоскость указания на то, что действия будущих государств-членов не соответствуют демократическим критериям членства в самом ЕС.

Это была достаточно запоздалая реакция на ситуацию с правами национальных меньшинств, а именно русскоговорящего населения в странах Прибалтики, которые уже в мае 2002 года подписали с Евросоюзом Договор о вступлении в ЕС. В целом российские попытки обратить внимание на ситуацию в государствах Прибалтики оказались не только запоздалыми, но и малоэффективными, о чем неоднократно впоследствии говорил министр иностранных дел Российской Федерации С.В. Лавров ${ }^{13}$.

11 Bastian K. Die Europäische Union und Russland. Multilaterale und bilaterale Dimensionen in der europäischen Aussenpolitik /NS-Verlag.Wiesbaden, Juni 2006. - s. 278. - S.95

12 См.: Adomeit H. Putins Westpolitik. Ein Schritt vorwärts, zwei Schritte zurück // SWP-Studie. - April 2005 - S8.

13 Лавров С.В, Демократия, международное управление и будущее мироустройство/ С.В. Лавров // Россия в глобальной политике. - 2004. - Ноябрь-декабрь. - ?6. Россия в глобальной политике (официальный электронный ресурc) URL: http://www.globalaffairs.ru/number/n_4201 
Тем не менее, это смещение акцентов в дискуссии об «общих ценностях» было свидетельством окончательного закрепления внешнеполитической и внутриполитической независимости РФ. Россия не имела реальных инструментов давления на внутреннюю политику ЕС или упустила их в силу запоздалой реакции. Но, благодаря возросшему внешнеполитическому и экономическому весу, она начала проводить более независимую линию в оценке действий Евросоюза, хотя и не применяя механизм политической обусловленности на двусторонней основе.

Отсутствие четкой стратегии в отношении РФ в сочетании с неэффективностью инструментов давления с целью изменения ее внутриполитического режима приводили к фактическому скатыванию отношений России и ЕС к европейско-китайской модели сотрудничества или ее близкому аналогу. Евросоюз как институт был озабочен окончательным завершением процесса расширения и всеми сопутствующими этому процессу внутренними изменениями. Отдельные государства Евросоюза, а фактически лидеры европейской интеграции, Франция, Германия, Италия демонстрировали подход, нацеленный на максимальное сближение России с ЕС по тем направлениям, где можно был получить практический и взаимовыгодный результат в достаточно короткие сроки.

Германия, например, активно лоббировала программу долгосрочного сотрудничества в энергетической сфере, идея которой принадлежала канцлеру ФРГ Г. Шредеру. В итоге программа стартовала в 2001 году.

В 2003 году последним фактом, который мог подтвердить этот вывод, стала та реакция ведущих европейских государств, которая сопровождала дело нефтяной компании «ЮКОС» М. Ходорковского и П. Лебедева. В ноябре 2003 г. на очередном саммите России и Евросоюза премьер-министр Италии Сильвио Берлускони открыто поддержал В.В.Путина по вопросам «дела ЮКОСа», ситуации в Чечне, прав человека и свободы прессы ${ }^{14}$. Именно на этом саммите Сильвио Берлускони был дано «прозвище» «солидного адвоката» ${ }^{15}$ России.

Россию в целом устраивала китайская модель сотрудничества с ЕС при символическом внимании к «общим ценностям» как основы, а не условия реализации сотрудничества.

14 Emerson, Michael, Tassinari, Fabrizio and Marius Vahl: New Agreement between the EU and Russia: Why, What and When? // CEPS Policy Brief - 2006. - May. - No.103. - P. 6.

15 Заявление для прессы и ответы на вопросы на пресс-конференции по итогам встречи на высшем уровне Россия - Европейский союз, 6 ноября 2003 г., Рим, Италия. Сайт Президента Poccии. URL: http://www. kremlin.ru/appears/2003/11/06/2339_type63377type63380_55128.shtml 


\section{4 год: переосмысление места и роли «общих ценностей» в рамках сотрудничества с Россией и ее ответная реакция}

2004 год формально стал серьезной попыткой кардинального переосмысления основ сотрудничества России и Евросоюза, стремлением совместить в новой стратегии в отношении России элементы реализма и идеализма. Несколько институтов Европейского Союза приняли аналитические документы, которые предлагали условно «обновленную» стратегию ЕС в отношении России. Этими документами стали «Доклад комитета Европейского Парламента по международным делам, правам человека и общей внешней и оборонной политике» (2004), «Сообщение Комиссии Европейских Сообществ Совету ЕС и Европейскому Парламенту» (2004) и «Заключение Совета ЕС по вопросам взаимоотношений с РФ» (2004). Европейские исследователи неоднократно подчеркивали, что главной причиной пересмотра отношений была боязнь того, что авторитарные тенденции во внутренней политике России отразятся в сфере внешнеполитической деятельности ${ }^{16}$. Китайская модель сотрудничества с Россией не устраивала европейскую сторону.

Общественное мнение Евросоюза, с которым приходилось считаться европейским лидерам, склонялось к мысли, что усиление российского внешнеполитического влияния и значимости в мировой экономике приведет к тому, что Россия будет применять жесткие меры политического давления на своих соседей ${ }^{17}$.

Отчасти принятие трех аналитических документов со стороны различных институтов ЕС должно было успокоить общественные опасения. Новый комиссар ЕС по внешним связям Б. Ферреро-Вальднер, отражая упреки по поводу отсутствия критики российской внутренней политики, заявляла, что общественность не должна обманываться отсутствием публикаций на эту тему, так как «критический диалог» часто проходит за закрытыми дверями ${ }^{18}$.

Аналитические доклады стали попыткой оценки факторов, тормозящих реализацию целей и задач сотрудничества с Россией, а также внутренней консолидации ЕС в отношении перспектив развития партнерства с Россией. Первый срок президентства В.В. Путина был охарактеризован явным ослаблением приверженности «общим ценностям». Список примеров, подтверждавших данное заявление, был развернутым.

\footnotetext{
16 Timmermann H. Die deutsch-rusischen beziehungen im europäischen Kontext // Internationale Politik und Gesellschaft. - 2007. - No. 1. - S.107.

17 Spanger H.J. Partnerschaft: strategisch, pragmatisch oder selektiv? Die EU und Russland auf der Suche nach einem neuen Vertrag. // HSFK Standpunkte. - 2006. - ?6. - S.10.

18 Schuette R. EU-Russia relations: Interests and values - A European perspective // Carnegie Papers. Russian and Eurasian Programme. - December 2004. - No. 54 - P.25.
} 
Темы: состояние СМИ, прав человека и демократии в России в целом, ситуация в Чечне звучали в ходе дискуссии об «общих ценностях» на протяжении 2000 - 2003 гг. и закономерно нашли свое отражение в Докладе Комитета Европейского парламента по международным делам ${ }^{19}$, Сообщении Еврокомиссии $^{20}$. В данном случае претензии представителей ЕС не содержали ничего нового. Предмет дискуссии в рамках вопроса приверженности «общим ценностям» был стопроцентно предугадываемым.

Европарламент подчеркнул, что ЕС недооценил сложность процесса демократизации в России, поэтому функционирование такого финансового инструмента, как программа ТАСИС, оказалось неэффективным. Отмечая факт несоответствия политики российских властей «ценностным» установкам сотрудничества, Еврокомиссия заявила о необходимости строить отношения с Россией на прагматической основе и отстаивать интересы Евросоюза ${ }^{21}$.

Фактически, два института ЕС сделали вывод о том, что Россия представляет собой субъект вне «ценностного» измерения Европы, который в то же время плохо интегрируем в данное измерение на тех условиях, которые ему предлагаются.

Однако, несмотря на констатацию фактов, которые были уже давно подтверждены практическими реалиями конца 1990x - начало 2000x гг., ни один из институтов не мог предложить более эффективные инструменты «европеизации» России, чем те, которые уже применялись.

Европейские аналитики, так же как и представители институтов ЕС, признавали неэффективность и нецелесообразность применения санкций к России как инструмента «ценностной» трансформации. Чрезмерный акцент на «общих ценностях» рассматривался как мера, которая в итоге приведет к отчуждению России от ЕС и «Запада» в целом ${ }^{22}$. Европарламент ${ }^{23}$ четко обозначил невозможность выстраивания отношений с Россией по «китайскому образцу» (минимум критики внутриполитического развития при интенсивном экономическом сотрудничестве).Именнопоэтому формулированиеЕвросоюзом собственных интересов, целей и приоритетов в отношениях с «новой» Россией

19 Report with a proposal for a European Parliament recommendation to the Council on EU-Russia relations, (2003/2230 (INNI), Final A5-0052/2004, Brussels, February 2, 2004.

20 Communication from the Commission to the Council and to the European Parliament. On relations with Russia, COM (2004) 106 final, Brussels, February 10, 2004.

21 Communication from the Commission to the Council and to the European Parliament. On relations with Russia, COM (2004) 106 final, Brussels, February 10, 2004.

22 Grant C. How to help Russia //CER Bulletin. 2000. - February. - Issue 10; Grant C. Learning to live with new Russia // CER Bulletin. - 2004. - October/November - Issue 38; Barysch K. The EU and Russia. Strategic partners or squabbling neighbours //CER. - May 2004. - P.65

23 Report with a proposal for a European Parliament recommendation to the Council on EU-Russia relations (2003/2230 (INNI), Final A5-0052/2004, Brussels, February 2, 2004. 
оказывалось приоритетной задачей, также как и последовательность и координация действий государств - членов $\mathrm{EC}^{24}$.

2004 год и принятие трех аналитических докладов со стороны институтов ЕС едва ли можно считать попыткой перевода политического диалога, или партнерства в целом в другую систему координат. Все документы ЕС констатировали в письменном виде реалии конца 1990x - начало 2000х гг., а именно несостоятельность и провал политики ЕС по распространению своей системы ценностей на территории России, но не предлагали новых решений «российского вопроса». В отсутствии единого видения перспектив и целей партнерства с Россией, Евросоюз продолжал «метаться» между построением взаимоотношений сугубо на основе прагматических интересов ЕС, которые были озвучены в документах расплывчато, и сочетанием похода, основанного на «общих ценностях» и «интересах».

Фактически, в отсутствии стратегической цели партнерства и опасений последствий постановки подобной цели, Евросоюз был обречен, по инерции, говорить с Россией на сугубо техническом языке (энергетика). Россия, уже в 2000 гг, была готова соблюдать правила и стандарты ЕС, но лишь в том случае, если у нее будут права в области принятия решений по этим стандартам ${ }^{25}$.

Тем не менее, как отмечал, Д.А. Данилов, ведущий российский специалист в области отношений Россия - EC, отказ от условно интеграционной и демократической стратегии мог быть расценен как поддержка современных авторитарных тенденций в России ${ }^{26}$. Фактор «общих ценностей» в диалоге с Россией оставался элементом самоопределения на внешнеполитической арене как «нормативного» субъекта». Для российского руководства было важно отсутствие каких-либо оценочных суждений в отношении вопроса об «общих ценностях».

В итоге стороны нашли оптимальный инструмент реализации своих целей. По итогам Гаагского саммита РФ-ЕС в ноябре 2004 г. была образована совместная рабочая группа по правам человека ${ }^{27}$.

24 Relations with Russia. Council Conclusions. 6294/04 (Presse 49). Brussels, February 23, 2004// Сайт Совета Европейского Союза (элекронный ресурc) URL: http://www.consilium.europa.eu/ueDocs/cms_Data/docs/ pressData/en/gena/79150.pdf

25 Суслов Д.В. «Европейский выбор» под вопросом. Москва должна сделать ставку на осторожную интеграцию в ЕС/ Д.В. Суслов //Независимая газета. - 2004. - 05 ноября.

26 Данилов Д.А. Отношения РФ-ЕС и миротворчество на постсоветском пространстве/ Д.А. Данилов // В кн.: Россия и объединяющаяся Европа: перспективы сотрудничества, под. ред. Федорова В.П. (отд. ред.), Потемкиной О.Ю., Кондратьевой Н.Б. - Москва: ИЕ РАН, АЕВИС. Фонд им. Фр. Эберта. - «Рус. Сувенир» 2007.Россия - 120 с. - С.78.

27 Аналогичные механизмы диалога по правам человека функционируют в рамках отношений Европейского союза с Китаем и Ираном. 
Целью работы данной группы было создание механизма постоянного и равноправного диалога по проблемам прав человека не только в России, но и в странах Европейского союза.

В долгосрочной перспективе появление подобной рабочей группы было оптимальным выходом из ситуации, так как позволяло придать проблеме прав человека и демократии более низкий статус в рамках двусторонней повестки. В результате чего, переговоры в рамках саммитов можно было не осложнять проблематикой соблюдения прав человека, и стороны могли спокойно сконцентрироваться на экономических и внешнеполитических вопросах. В дискуссии об «общих ценностях» в рамках политического диалога ЕС - Россия появление подобной рабочей группы предоставляло возможность высказывать взаимные претензии бездополнительного обострения двусторонних отношений России и Евросоюза.

Позднее, Рина Кионка, личный представитель Х.Соланы по правам человека, подчеркивала, что диалог Россия-ЕС по правам человека практически не приносит результатов, но даже такой диалог лучше, чем его полное отсутствие ${ }^{28}$.

Для российской стороны вопрос приверженности «общим ценностям» в 2004 году был напрямую связан с соблюдением прав русскоговорящих меньшинств в Эстонии и Латвии. Это был не первый раз, когда Россия обращала внимание на невыполнение Копенгагенских критериев членства в ЕС. У России был реальный инструмент воздействия на ЕС в этом вопросе, а именно решение о распространение или нераспространение Соглашения о Партнерстве и Сотрудничестве на новые государства-члены ЕС. Россия заявляла, что данный процесс нельзя считать автоматическим. Но в итоге степень значимости прав русскоговорящих меньшинств не оказалась достаточно высокой для российского руководства, по сравнению с темой вступления в ВТО, которая доминировала в российской повестке в 2004 году или подписания соглашения об упрощении визового режима и реадмиссии в 2005 году. Россия фактически сама способствовала практики применения двойных стандартов. Европейский ответ был кратким: «ситуация имеет свои нюансы, идет работа с каждой стороной, но возможно проблему придется решать будущим поколениям» ${ }^{29}$.

28 Lobjakas A. Activists say EU-Russia rights dialogue at «dead end»// Radio Free Europe/Radio Liberty - 2007. 3 October.

29 Пресс-конференция по итогам встречи на высшем уровне Россия - Европейский союз, 10 мая 2005 г., Москва, Кремль // Сайт Президента России (официальный электронный ресурc) URL: http://www.kremlin. ru/appears/2005/05/10/1823_type63377type63380type82634_88013.shtml 


\section{«Дорожные карты» и категория «общие ценности»: на пути подписания новой договорно-правовой базы отношений (2005-2007 гг.)}

В историю взаимоотношений России и Евросоюза 2005 год вошел как год принятия четырех «дорожных карт». «Дорожные карты», согласованные с российским политическим руководством на двусторонней основе, были призваны заполнить вакуум в политических отношениях России и Евросоюза, а также обозначить те стратегические цели, о необходимости поиска которых, говорили различные институты ЕС еще в 2004 году.

В итоге они скорее определили очертания тех сфер, взаимодействие в которых представляет реальный интерес для двух субъектов. Являясь, по сути, соглашениями о намерениях, они подписывались представителями ЕС и России, но не ратифицировались национальными правительствами. Данный шаг позволил избежать трудностей, связанных с проецированием новыми странами-членами ЕС особенностей собственного видения будущих взаимоотношений с Россией. Юридический статус «дорожных карт» лишь на время отсрочил необходимость решения проблемы согласования различных позиции внутри ЕС по российской проблематике, в том числе и по вопросу «общих ценностей». По существу «дорожные карты» стали политическими декларациями, туманными по срокам своей реализации.

Тем не менее, в определении места категории «общие ценности» в политическом диалоге с ЕС, России удалось добиться ряда значительных побед. Концепт «общих ценностей», по-прежнему, определялся через набор демократических принципов и уважение прав человека, в особенности прав лиц, принадлежащих к меньшинствам. Ссылка на «общие ценности» как основы взаимоотношений содержалась в двух дорожных картах: по общему пространству внешней безопасности и общему пространству свободы, безопасности и правосудия. РФ добилась от Евросоюза исключения из «общего пространства свободы, безопасности и правосудия» формулировки, обязывающей Россию соблюдать права человека и демократии, чего так хотел Евросоюз ${ }^{30}$. Также была отклонена идея о включении в «дорожные карты» ссылку на необходимость улучшения гуманитарного положения и проведение честных и свободных выборов в Чечне ${ }^{31}$.

Евросоюз стремился определить термин «свобода» через понятия «демократия» и «права человека». Российская сторона подписала документ

\footnotetext{
30 Emerson M. EU-Russia. Four common spaces and the proliferation of the fuzzy // CEPS Policy brief. - May 2005. No. 71

31 Russland Analysen.- 2005. - Mai 20. - ?66. - S.2, 4
} 
лишь когда, под понятием «свобода» стала подразумеваться неограниченная возможность для перемещений. В итоге в «Дорожной карте» по общему пространству свободы, безопасности и правосудия приверженность «общим ценностям» отмечена лишь в преамбуле ${ }^{32}$.

С точки зрения места категории «общие ценности» в политическом диалоге России и ЕС, дорожные карты закрепили, хотя и с опозданием, желаемый для России политико-правовой формат: отсутствие требования о соблюдении «общих ценностей» как основы движения от «кооперации» к «интеграции» или углублению двусторонних контактов.

Российские эксперты подчеркивают, что понимание того, как должен происходить процесс «интеграции» между Российской Федерацией и ЕС, изменилось. Первоначально под процессом интеграции подразумевалось одностороннее сближение российской законодательной, политико-правовой и экономической моделей с европейской. В дорожных картах речь шла скорее о двустороннем сближении, основанном на согласовании и обмене интересами. ${ }^{33}$

Однако необходимо отметить, что Европейский Союз не стремился с легкостью отказаться от изначальной концепции «ограниченной европеизации» ранних 1990х годов, по крайней мере в экономической сфере. Дорожная карта по общему экономическому пространству содержит многочисленные положения о необходимости гармонизации российского законодательства, совместимости, сближении, при этом, вполне естественно ${ }^{34}$, что экономическая модель ЕС и его технические стандарты воспринимаются как априори лучшие. Как правило, эти стандарты действительно выступали как более развитые по сравнению с российскими, но их принятие не всегда было выгодно для определенных кругов внутри руководящей элиты РФ.

Формально 2005 и 2006 годы были показательными с точки зрения очередной попытки европейских партнеров реализовать прагматичный подход: отсутствие приверженности «общим ценностям» не должно мешать сотрудничеству там, где велика взаимозависимость и есть «общие интересы».

\footnotetext{
32 «Дорожная карта» по общему пространству свободы, безопасности и правосудия, Москва, 10 мая 2005 года // МИД России (официальный электронный ресурс). URL: http://www.mid.ru/ns-dos.nsf/ 162979df2beb9880432569e70041fd1e/432569d800223f34c3256ffe002a7865?OpenDocument

33 Лукьянов, Ф. Новое соглашение между Россией и Европейским Союзом: условия и возможности/ Ф. Лукьянов // In Partnership with Russia in Europe. Scenarios for a Future Partnership and Cooperation Agreement. Fourth Discussion Circle Meeting Morozovka (near Moscow). - 2006. - September 10-12.

34 «Дорожная карта» по общему экономическому пространству, 10 мая 2005 г.// Президент России (официальный электронный ресурc) URL: http://www.kremlin.ru/events/articles/2005/05/87950/152811.shtml
} 
Тем не менее, утверждать, что «разрыв ценностей» исчез из повестки дня России и ЕС, было преждевременно. Обсуждение «разрыва» в диалоге о ценностях было перенесено из плоскости публичной официальной риторики в плоскость неформальных встреч или внутренние документы ЕС. В рамках одной из таких встреч в октябре 2006 г. европейская сторона отметила, что убийство журналиста Анны Политковской должно быть расследовано, а виновные - привлечены к ответственности. Темы давления российских властей на СМИ, институты гражданского общества стали затрагиваться в отдельных внутренних документах Европейского союза ${ }^{35}$.

Ключевую роль в дискуссии об «общих ценностях» России и ЕС должна была сыграть ранее созданная рабочая группа по правам человека. Проблема заключалась в том, что встречи этой группы проходили при «закрытых дверях». После этих встреч не было сделано никаких совместных заявлений или деклараций, единственным источником информации были прессрелизы, выпускаемые европейской и российской сторонами по отдельности. Невозможность согласовать ни одно совместное заявление, различная тематика односторонних пресс-релизов скорее подтверждали, что консенсус и согласие по поводу места и роли категории «ценности» остается лишь видимостью.

В 2006 г. Евросоюз внес ряд предложений по изменению работы данной группы. Было предложено расширить число участников из различных министерств. Формальный механизм должен был стать менее формальным с привлечением представителей $\mathrm{HПО}^{36}$.

Данные изменения не были поддержаны российской стороной. Они рассматривались, как попытка применить очередной инструмент давления и воздействия на внутриполитическую ситуацию со стороны ЕС. Россия заявила, что созданный формат деятельности рабочей группы по правам человека предполагает участие только дипломатов. В дискуссии об «общих ценностях» Россия стремилась максимально ограничить участие широкой общественности, что, для Евросоюза, было признаком укрепления авторитарных тенденций во внутренней политике и отдалением от категории «общие ценности». В результате Евросоюз проводил консультации с российскими НПО накануне официальных встреч рабочей группы.

35 Presidency press statement - EU/Russia human rights consultations, Brussels, September 8, 2005; Press release. EU and Russia hold fourth round of Human Rights Consultations, November 8, 2006; Press release. EU and Russia hold the fifth round of their Human Rights Consultations, May 04, 2007; Presidency press statement. EU/Russia human rights consultations, March 10, 2007; Presidency press statement on EU/Russian Federation human rights consultations, April 17, 2008; Пресс-релиз, освещающий третью консультацию Россия-EC (3 марта 2006 г., Вена) обнаружить не удалось. На сайте австрийского председательства есть лишь упоминание об этой встрече, но о повестке ничего не говорится. 36 Klitsounova E. Promoting human rights in Russia by supporting NGOs: How to improve EU strategies // CEPS
Working Document - April 2008. - No. 287. - P.14 
В свете разработки нового формата взаимоотношений России и ЕС, европейские парламентарии отмечали, что статус рабочей группы должен быть повышен в рамках нового базового соглашения Россия-EC ${ }^{37}$. Однако это представляется маловероятным в будущем, так вновь поставит Россию в ситуацию «объекта» оценки в вопросе приверженности «общим ценностям». От подобного формата взаимоотношений Россия отошла уже в конце 1990х гг.

К концу 2000х гг. в дискуссии об «общих ценностях» обозначилась новая тенденция, связанная с приданием дополнительной роли категории «общие ценности» со стороны ЕС. Не секрет, что в качестве ключевого интереса в партнерстве с Россией в 2005-2006 гг. выступало энергетическое сотрудничество. Разработка общих принципов энергетического диалога, возможный «энергетический шантаж» со стороны России, доступ европейских партнеров к российской энергетической инфраструктуре, присоединение России к Энергетической Хартии доминировали среди остальных тем российско-европейского взаимодействия, особенно на фоне российскоукраинского «энергетического скандала» начала 2006 г.

В итоге в Европе зазвучали опасения следующего характера. Зависимость от России (в плане энергоресурсов) может стать настолько значительный, что будет закрыто обсуждение недостатков российской демократии. Таким образом, диалог об «общих ценностях» стал выступать в качестве фона для энергетического диалога. Российские эксперты также считали, что проблемы российских инвестиций в экономику ЕС, подписание Энергетической Хартии часто взаимосвязаны с политическим давлением на Россию в сфере демократии и прав человека.

Для политического диалога России и Европейского Союза 2007 год стал периодом острой полемики партнеров по поводу наличия общей системы ценностей и основ будущего сотрудничества. В ноябре 2007 года должно было истечь Соглашение о Партнерстве и Сотрудничестве. Вопросы пересмотра, дополнения или сохранения привычной повестки дня и принципов взаимоотношений России и ЕС стали особенно актуальными.

Перед началом переговоров по новой договорно-правовой базе сотрудничества стороны фактически обозначили друг для друга «красные линии» в дискуссии об «общих ценностях».

Во-первых, российская сторона в очередной раз настойчиво продемонстрировала представителям Евросоюза, что давление на Россию

37 European Parliament resolution on Chechnya after the elections and civil society in Russia, P6_TA(2006)0026, January 19, 2006; Europaen Parliament resolution on the EU-Russia summit held in Sochi on 25 May 2006, P6_ TA(2006)0270, June 15, 2007; European Parliament resolution of 26 April 2007 on Russia, P6_TA(2007)0169. 
в вопросе приверженности общей системе ценностей невозможно. В мае 2007 года в московском аэропорту были задержаны руководители «Марша Несогласных», Эдуард Лимонов и Гарри Каспаров, накануне очередной акции движения в Самаре в период саммита Россия - Евросоюз. Это был показательный пример «суверенитета» российского политического руководства в вопросе интерпретации понятий «свобода собрания» и «свобода слова».

Во-вторых, российское руководство в преддверии истечения срока действия СПС прямо указывало представителям Евросоюза на наличие «двойных стандартов» в дискуссии об «общих ценностях». Претензии российской стороны заключались в пренебрежении озабоченностями России: нарушении прав русскоязычного населения в Латвии и Эстонии, переносе «Бронзового солдата» в Таллине в апреле 2007 г. и намеренном неоказании медицинской помощи со стороны властей пострадавшему во время демонстрации ${ }^{38}$.

Российские попытки воздействовать на Евросоюз в решении этих вопросов не имели успеха. Еще в 2004 г. министр иностранных дел РФ С.В.Лавров заявлял, «в диалоге с ЕС России с большим трудом удается доказать очевидную и подкрепленную объективными факторами несправедливость того положения, в котором оказались национальные меньшинства в Латвии и Эстонии» ${ }^{39}$. Реакция европейской стороны заключалась в признании этой проблемы излишни политизированной ${ }^{40}$.

В итоге 2007 году Россия «обвиняла» государства-члены Евросоюза и институты ЕС в лицемерии в вопросе позиционирования Европы как нормативного игрока, способного развивать партнерские отношения лишь с государствами, вписывающимися в стандарт: европейские ценности. Российское руководство неоднократно отмечало, что у Евросоюза есть стратегические партнеры, система ценностей которых может кардинальным образом отличаться от той, которую пропагандирует Европа ${ }^{41}$.

С. А. Караганов так прокомментирует ситуацию, сложившуюся во взаимоотношениях России и ЕС: «Россия демонстративно и жестко перестала идти на уступки, делать вид, что ее устраивают правила игры, сложившиеся в годы российской слабости. До прошедшего года старый Запад пытался не

38 Бронзовый солдат в Таллине // Материалы «Российской газеты» (официальный электронный ресурс) URL: http://www.rg.ru/sujet/2556.html

39 Лавров С.В, Демократия, международное управление и будущее мироустройство // Россия в глобальной политике. - 2004. - Ноябрь-Декабрь. - ?6.

40 Р.Кионка, специальный представитель X. Соланы по правам человека «Искусственное придание этой проблеме (о правах русскоязычного населения.) политического характера только мешает представителям меньшинств». Критика - неотъемлемая часть демократии // Вестник Представительства Европейской Комиссии в Российской Федерации. - 2007. - Декабрь. - ?4.

41 В.В. Путин: «У Евросоюза есть другие страны, с которыми Евросоюз поддерживает стратегические отношения. А там и проблема Гуантанамо, и проблема смертной казни, которая не входит в число моральнонравственных ценностей Евросоюза». 
слушать мнения Москвы и придерживаться с модификациями политики, выбранной в 1980-е годы. В 2007 году произошел перелом. В западных столицах поняли: Москва изменила политику всерьез и надолго. Это вызвало недовольство. Россию выписали из списка демократических или демократизирующихся держав, в который она условно вносилась, когда вела себя более послушно» ${ }^{42}$.

«Разрыв» в дискуссии об «общих ценностях», давно присутствовавший в политическом диалоге России - ЕС, хотя и без санкций в качестве последствия в 2007 году стал вновь более открытым для широкой общественности и подтвержденным на уровне первых политических лиц. Цена вопроса заключалась в том, стороны вплотную приблизились к необходимости формулирования разделов будущего двустороннего документа. В 2007 г. российская сторона просто констатировала, что формулировка раздела об «общих ценностях» в формате, отдаленно напоминающем политическую обусловленность, не возможна.

С точки зрения Москвы, Россия выстраивала собственную модель развития, которая имела право на существование, также как и европейские аналоги. В новой редакции Концепции внешней политики РФ июля 2008 г. было впервые заявлено, что в рамках универсальных принципов демократии и рыночной экономики могут сосуществовать и конкурировать разные ценностные ориентиры и модели развития.

\section{Содержание, место и роль категории «ценности» во взаимоотношениях России и ЕС в 2008-2011 гг.}

2008 год открыл новый этап во взаимоотношениях России и Евросоюза и был связан с началом переговоров по новой договорно-правовой базе сотрудничества. Речь идет уже не о подписании политических деклараций, какими были, например, «дорожные карты», а о юридически обязательном двустороннем договоре. Сторонам предстояло провести переговоры о том, что станет основой будущих взаимоотношений России и ЕС. Соответственно вопрос об «общих ценностях» должен был неизбежно возникнуть в повестке дня партнеров.

К сожалению, к моменту начала переговоров ни Россия, ни Евросоюз не усвоили тех уроков, которые были определены реалиями 1990х и 2000x гг. «Разрыв ценностей» присутствовал в рамках всех трех параметров: 
содержания, роли и места «общих ценностей» в политическом диалоге. К началу переговоров по новой договорно-правовой базе сотрудничества России и Евросоюз подошли с отсутствием единой разделяемой стратегической цели сотрудничества. В риторике о развитии «стратегического партнерства» не присутствовало ничего нового.

Стороны по-прежнему не могли понять, каким в конченом итоге должно стать это партнерство, дублируя то, что было заявлено в ранее принятых двусторонних декларациях, и на каких принципах должно строиться будущее партнерство.

Формально содержание «общих ценностей» оставалось неизменным. Ни одна из сторон его концептуально не оспаривала и не ставила под сомнение ценности в качестве основы сотрудничества. Но, подчеркивая свою принадлежность к европейской системе ценностей, рассматривая себя как одну из ветвей европейской цивилизации, Россия претендовала на правомерность собственной модели развития. В реальности эта модель развития к концу 2000x гг. оказалась довольно далека от общих с ЕС ценностей на уровне практики. Евросоюз политизировал «разрыв ценностей» лишь отчасти и лишь частично использовал его как инструмент давления или как предлог для отказа от более содержательного диалога.

Формально Россия действительно принадлежала к группе западных демократий с закрепленными в Конституции РФ правами и свободами человека. На практике, высокий уровень коррупции, отсутствие верховенства закона, высокий уровень использования административных ресурсов в политической борьбе действительно не позволяет говорить о том, что претензии представителей ЕС являются необоснованными.

В одном из последних документов ЕС о политики в отношении России содержалась достаточно объективная оценка реалий российской внутренней жизни. Европейский союз приветствовал укрепление государственной власти в России, в тоже время, отмечая тенденцию к ослаблению оппозиции и независимости СМИ, бюрократизацию и слабость гражданского общества. ${ }^{43}$

На протяжении восьми лет президентства В.В. Путина Россия укрепляла свои позиции в качестве значимого фактора европейской политики, без которого нельзя рассматривать, прежде всего, вопросы энергетики и безопасности, тем самым постоянно приближая себя к Европе во внешней политике, но постепенно удаляя себя от нее с точки зрения функционирования государственных институтов. 
С другой стороны, Евросоюз вследствие отсутствия внутреннего единства в отношении России, обусловленного вступлением в ЕС государств ЦВЕ с особой исторической памятью в отношении России, оказался не в состоянии полностью отойти от попыток ее ассимиляции по западноевропейскому образцу. Желание влиять на ход внутренних реформ РФ присутствовало, но поиск новых инструментов воздействия на Россию не увенчался успехов. В итоге ЕС ограничивался риторическим давлением.

В подобной ситуации баланс по поводу единого понимания места и роли категории «общие ценности» в сотрудничестве между Россией и ЕС едва ли мог быть найден. В отсутствии понимания Россией и Евросоюзом невозможности нахождения реального, а не риторического консенсуса по вопросу «общих ценностей» по всем трем параметрам: содержанию, месту и роли, дискуссия полностью исчезла из повестки дня партнеров.

Необходимо отметить, что даже августовская война 2008 года, в период которой Россию обвиняли в несоответствии «общим ценностям», т.е. в нарушении Хельсинского Заключительного Акта, существенно не изменила ситуацию, а скорее подтвердила общую тенденцию всего периода партнерства России и ЕС. В отсутствии реальных инструментов влияния на трансформацию российской политики и объективной значимости России любое нагнетание напряжения по поводу приверженности «общим ценностям» оказалось невыгодным для ЕС. В итоге «дискуссия» было отодвинута на второй и третий план.

После войны в Южной Осетии Европейский Совет действительно принял «условные» меры в ответ на «непропорциональное использование Россией силы». В целом позиция ЕС оказалась достаточно сбалансированной. Были лишь приостановлены переговоры по новому соглашению о партнерстве и сотрудничестве, которые начались в июне 2008 г. Взгляды таких государств как Литва и Польша о введении санкций в ответ на «разрыв ценностей» с ЕС не нашли свое отражение на практике.

Это был второй прецедент в истории взаимоотношений двух партнеров, когда стороны явно по-разному расставили приоритеты в рамках Хельсинского Заключительного Акта, а фактически по-разному трактовали «общие ценности» во внешней политике. Но значимость России как партнера не позволила заморозить отношения.

Российская и европейская сторона предпочли вполне традиционный выход из ситуации, сделав выбор в пользу продолжения диалога, несмотря на противоречивые оценки действий друг друга. Российской Федерации была не нужна изоляция из-за признания независимости Южной Осетии и Абхазии, но в тоже время она не была намерена отступать от тех решений, которые, 
по мнению европейских партнеров, явно противоречили общей системе ценностей. Европейцы, в свою очередь, осознавали бессилие изменить данную ситуацию, а значит и бессмысленность антагонизма.

Три блока вопросов: преодоление глобального экономического спада, инвестирование в энергетический сектор в условиях финансового кризиса, обеспечение стабильных поставок энергоносителей в зависимости от объемов потребления энергии в Европе и на взаимовыгодных условиях требовали от ЕС объективной гибкости в вопросе об «общих ценностях» с Россией.

Отсутствие дискуссии о приверженности сторон «общим ценностям» не означал, что этот вопрос перестал быть частью политического диалога России и Евросоюза. Реакция, которую выразила европейская общественность и официальные лица по поводу программы «Партнерство для Модернизации», заявленной на саммите Россия - ЕС в ноябре 2009 г., подтверждает, что «общие ценности» по-прежнему продолжают играть роль инструмента трансформации внутриполитического режима РФ, при этом не только для Брюсселя, но и для многих кругов в Москве.

В качестве официальной цели программы было заявлено содействие в решении задач модернизации экономики России и всего комплекса отношений РФ-ЕС с учетом уже имеющегося опыта их взаимодействия. Глава Еврокомиссии, комментируя данный проект, подчеркнул, что модернизация не возможна без верховенства закона и широкого политического диалога. По мнению Еврокомиссии, жизнеспособное плюралистическое общество является необходимым элементом любого современного государственного устройства ${ }^{44}$.

В 2010 году, когда был принят Рабочий план программы «Партнерство для Модернизации», Евросоюз продолжал настойчиво демонстрировать свой подход к пониманию модернизации. Х. Ван Ромпей, президент Евросоюза, подчеркнул, что «от имени руководителей государств и правительств 27 государств - членов ЕС, и я просил Вас двигаться по пути модернизации, основываясь на демократических ценностях, строя современную экономику с активным вовлечением гражданского общества. Евросоюз желает быть партнёром России в этом историческом движении» ${ }^{45}$.

Евросоюз вполне четко озвучил свою позицию. Приверженность «общим ценностям» необходима в тех проектах, к которым России проявляет

\footnotetext{
44 Пресс-конференция по итогам 24-го саммита Россия-ЕС. 18 ноября 2009 г., Стокгольм // Сайт Президента России (официальный электронный ресурс) URL: http://www.kremlin.ru/transcripts/6034

45 Пресс-конференция по итогам встречи на высшем уровне Россия - Европейский союз, 7 декабря 2010 г., Брюссель. // Сайт Президента России (официальный электронный ресурс) URL: http://news.kremlin.ru/ transcripts $/ 9730$
} 
значительный интерес, а Евросоюз скорее будет служить источником «знаний», «технологий» или «экспертной помощи».В реализации сотрудничества с Россией по вопросу модернизации, ЕС заявил о стремлении к двойной цели: экономической и политической трансформации России.

Рабочий план программы модернизации предполагал наличие двух подпунктов непосредственно связанных с достижением некой общей системы ценностей РФ и ЕС:

IV. Укрепление правовой среды, совершенствование инвестиционного и социального климата;

V.Содействие развитию контактов между людьми и укреплению диалога с гражданским обществом ${ }^{46}$.

В рамках программы модернизации ЕС объективно выступает в качестве «источника определенного вознаграждения» для РФ, однако это лишь отчасти позволяет этому институту диктовать принципы осуществления партнерства для модернизации.

Во-первых, в настоящий момент Евросоюз для России не может рассматриваться как единственный источник модернизации. Во-вторых, проект «Партнерство для Модернизации» едва ли когда-нибудь будет включать элемент какой-либо «обусловленности» доступа к знаниям и технологиям выполнением определенных ценностных требований. Слишком долго Россия отстаивала принцип равноправия как «ценность» в партнерстве с Евросоюзом. Подобный вывод закономерно сделать и относительно возможной договорноправовой базы сотрудничества России и ЕС.

В-третьих, реализация программы «Партнерство для модернизации» не является частью стремления быстро подтвердить приверженность сотрудничеству с западными партнерами. Лишь вследствие своей культурноисторической общности с Россией, Европа рассматривается как наиболее приемлемый и удобный партнер для модернизации.

В итоге, российская сторона едва ли будет форсировать выполнение «Партнерства для модернизации» на неприемлемых для нее условиях. Эта программа, безусловно, имеет огромный положительный смысл, если рассматривать ее как одну из нескольких концепций взаимоотношений России и Евросоюза. Но, скорее всего, сложность ее реализации будет заключаться не только в том, что стороны выделяет разные принципы, которые лежат в основе функционирования этого проекта.

46 Рабочий план мероприятий по реализации инициативы Россия - EC «Партнерство для модернизации», 7 декабря, 2010. URL: http://eeas.europa.eu/delegations/russia/documents/news/work_plan_ru.pdf 
Евросоюз не в состоянии ассимилировать Россию по западноевропейскому стандарту, но даже в рамках проекта «Партнерство для модернизации» он попрежнему живет парадигмами 1990х гг. При этом, весьма сомнительно, что при всех финансовых и экономических трудностях, которые испытывает в настоящий момент Европейский Союз, он готов идти на реальную техническую модернизацию России.

В тоже время очень трудно поставить под сомнение взаимозависимость между эффективной наукоемкой и технологически развитой экономикой и низким уровнем коррупции, функционирующим правовым полем, защитой инвестиционного климата. Однако, как отмечают эксперты международного дискуссионного клуба «Валдай»:

«Но наставительный тон, который был присущ Евросоюзу в предшествующий период, претензии на вмешательство во внутренние дела России и применение «двойных стандартов» не достигают цели и способны лишь оттолкнуть, что доказал накопленный опыт. Сближение может происходить, когда у российского общества и элиты появится реальный стимул двигаться к европейским ценностям и стандартам - общая цель совместного развития ${ }^{47}$.

Российская экспертная элита достаточно скептически оценивает возможные плюсы Партнерства для Модернизации, подчеркивая, что Россия и ЕС по-прежнему ведут «диалог глухих».

Ведущий российский эксперт по российско-европейским отношениям, С.А. Караганов отмечает, что «официальная Россия под модернизацией понимает по преимуществу модернизацию технологическую, или содействие российским корпорациям в бизнес-проектах. При этом россияне пока не готовы пожертвовать и толикой столь трудно отвоеванного суверенитета, обеспечивающего к тому же и неограниченные возможности безудержно воровать. Поэтому принимать европейские технические стандарты не хочется: сдаем суверенитет. Хотя российский президент и указывал, что при строительстве по тем стандартам дороги в России стоили бы дешевле» ${ }^{48}$.

Причины, которые объясняют трудности реализации программы «Партнерство для модернизации», можно отнести и ко всей дискуссии по поводу новой договорно-правовой базы сотрудничества России и Евросоюза. Евросоюз по инерции следует ранее выбранной политико-правовой модели взаимоотношений. Россия не приемлет данную модель, причем не только с

47 К Союзу Европы //Аналитический доклад российской группы международного дискуссионного клуба «Валдай». - 2010. - 31 августа - 7 сентября.

48 Караганов С.А.Союз Европы: последний шанс?/ С.А. Караганов // Российская газета. - 2010. - 9 июля. N5229 
точки зрения наличия оценочных суждений со стороны Евросоюза, но и с точки зрения реальной приверженности заявленным принципам сотрудничества.

В итоге Россия и Европейский Союз, проделав достаточно быстрый путь по сближению российской и европейской систем ценностей, оказались в ситуации стагнации, когда сближение не только прекратилось, но и возникает отход от ранее проделанных достижений. При этом Евросоюз, во многом за счет роли новых государств-членов ЕС, не может обновить ранее заявленный подход к «общим ценностям» в рамках политического диалога России и ЕС. Россия, напротив, не совсем четко понимает, что Евросоюз нельзя рассматривать только как источник хозяйственного потенциала. В результате стороны вновь и вновь оказываются в ситуации «разрыва ценностей», который был частично преодолен в 1990е, и усилился на протяжении 2000х гг. 
KONCEPTUALNE PODEJŚCIE DO DIALOGU O RÓŻNYM IDEOLOGICZNYM ROZUMIENIU WARTOŚCI EUROPEJSKICH MIĘDZY ROSJA A UNIA EUROPEJSKA

Ideologiczna debata pomiędzy Rosją i UE to problem wartości politycznych. Analizie poddano różne podejścia do takich wartości jak demokracja, prawa człowieka i gospodarka rynkowa. Przedstawiono również chronologiczną analizę poszczególnych etapów tej debaty wartości podczas kadencji prezydenckich Borisa Eltsina, Władimira Putina oraz Dmitrija Miedwiediewa. Wpływ zobowiązań prawnych, nie obojętną (neutralną) lecz opartą na określonych wartościach politykę zewnętrzną UE w świetle Traktatu z Lizbony również stanowi przedmiot niniejszej analizy badań. 


\section{A CONCEPTUAL AND PRACTICAL APPROACH TO SOLVING DIFFICULT PROBLEMS BETWEEN RUSSIA, THE EUROPEAN UNION AND ITS MEMBER STATES}

The ideological debate between Russia and the European Union is a problem of political values. Various approaches to such values as democracy, human rights and the market economy were analysed in the present study. A chronological analysis of the particular stages of this debate regarding values during the terms of office of Presidents - Boris Yeltsin, Vladimir Putin and Dmitri Medvedev is also presented. The impact of legal obligations on the external policy of the European Union, which is neutral but based on certain values, in the light of the Treaty of Lisbon, is also a subject of the present study.

Key words:

The European Union, Russia, values, external policy, democracy 